izv. prof. dr. sc. Marina Đuranović

Učiteljski fakultet Sveučilišta u Zagrebu

marina.duranovic@ufzg.hr

doc. dr. sc. Irena Klasnić

Učiteljski fakultet Sveučilišta u Zagrebu

irena.klasnic@ufzg.hr

Irena Matešić, mag. paed.

Dječji vrtić „Travno“

pedagog@dv-travno.hr

\title{
POTICANJE DJEČJE KREATIVNOSTI U PREDŠKOLSKIM USTANOVAMA
}

Sažetak: Uz obitelj, predškolske ustanove predstavljaju najvažniji čimbenik rasta i razvoja djeteta predškolske dobi. To su mjesta dječjega življenja, razvoja, učenja i igre. Kurikulum predškolskih ustanova mora biti fleksibilan, otvoren, prilagođen dječjim potrebama i mogućnostima. Kreativnost mora biti temelj predškolskoga kurikuluma. Dječja se kreativnost može poticati i razvijati kroz sve aktivnosti u predškolskim ustanovama: igru, glazbene, likovne, dramske, kineziološke i brojne druge aktivnosti. U poticanju dječje kreativnosti važnu ulogu imaju odgojitelji, a da bi ju kod djece uspješno razvijali moraju biti svjesni njezine važnosti te i sami trebaju raditi u okruženju koje potiče njihovu kreativnost.

Cilj je ovoga rada osvijestiti važnost poticanja i razvoja dječje kreativnosti $i$ stvaralaštva još od najranije dječje dobi kao jedne od osam ključnih kompetencija za cjeloživotno obrazovanje.

Ključne riječi: kreativnost, odgojitelj, otvoreni kurikulum, predškolska ustanova, stvaralaštvo

\section{POGLEDI NA DIJETE NEKAD I DANAS}

S razvojem društva mijenjao se i pogled na dijete kao i na njegov položaj u društvenoj zajednici. U antičkoj Grčkoj u znatnoj se mjeri razlikovao odgoj djece u Sparti i Ateni. Spartanski odgoj bio je poznat kao strog i vojnički, s ciljem ojačanja duha i tijela te formiranja budućih ratnika. Dječaci su se do sedme godine odgajali 
u obiteljima nakon čega je njihov odgoj preuzimala država. Naglasak je bio na tjelesnom odgoju, a svladavale su se samo osnove čitanja i pisanja. Djevojčice su također bile vojnički odgajanje, no ne tako strogo kao dječaci i ostajale su u obiteljima. Atenski odgoj bio je puno blaži i svestraniji. Uz tjelesni odgoj, djeca su poučavana osnovama umjetnosti te prirodnim i društvenim znanostima. Odgojni cilj bio je skladan razvoj duha i tijela (Zaninović, 1988). Djeca su se odgajala u obitelji, no država ih je nadzirala kako bi se uvjerila da to rade na pravi način (Miljković, 2009). Otac je kao nositelj odgoja odlučivao hoće li novorođenče prihvatiti ili odbaciti (Fass, 2004). U antičkom Rimu više se cijenilo obrazovanje, a cilj je bio odgojiti dobroga govornika i građanina odanoga Republici (Zaninović, 1988). Općenito, možemo zaključiti da su djeca u to doba bila vlasništvo oca koji je odlučivao o njihovoj sudbini te ih je mogao surovo kažnjavati, prodati i ubiti.

U srednjem vijeku velik utjecaj na odgoj djece imala je Katolička crkva. Od djece se očekivala bezuvjetna poslušnost, umjerenost, rad. Disciplina je bila stroga, a glavna odgojna metoda grubo fizičko kažnjavanje djeteta (Žlebnik, 1955). U doba humanizma i renesanse znatno se mijenja pogled na dijete i njegov odgoj. Težilo se odgoj prilagoditi individualnim osobinama djeteta, zagovarao se cjeloviti dječji razvoj (tjelesni, intelektualni i moralni) i izbjegavanje fizičkoga kažnjavanja (Zaninović, 1988). U 18. stoljeću Jean-Jacques Rousseau, poznati francuski filozof i pedagog, u središte odgojnoga djelovanja stavlja dijete, naglašavajući pritom važnost dječje aktivnosti. Zagovarao je prirodni odgoj, odnosno odgoj djeteta u skladu s njegovim urođenim osobinama. Smatrao je da se dijete po prirodi rađa dobrim te da ga treba odgajati u skladu s tom prirodom (Žlebnik, 1955).

U 19. stoljeću (u doba industrijske revolucije) djeca su teško živjela i bila su izrabljivana. Radila su u rudnicima ili tvornicama i do 14 sati dnevno. Poslodavci su ih rado zapošljavali jer su bila poslušna i jeftina radna snaga. Dječji rad predstavljao je znatnu pomoć obiteljskim prihodima (Fass, 2004). Pred kraj 19. stoljeća dolazi do ograničavanja radnoga vremena djece kao i minimalne dobi u kojoj se dopušta rad te se time poboljšavaju dječji životni uvjeti.

U 20. stoljeću mijenja se pogled na dijete i njegov položaj u društvu. Djeca se nastoje više zaštititi. Ellen Key (1849.-1926.) u svojem poznatom djelu Stoljeće djeteta iznosi svoja promišljanja o djetetu, njegovu odgoju i obrazovanju. Autorica naglašava važnost vraćanja djetinjstva djeci, kritizira izrabljivanje djece te ističe njihovo pravo na skrb, dom i obrazovanje (Fass, 2004).

Današnja djeca odrastaju u socijalno kompleksnom, tehnički i tehnološki vrlo razvijenom i kulturno bogatom i raznolikom svijetu (Šagud, 2015a). Suvremeno društvo stvara novu sliku o djetetu i djetinjstvu. Na djetinjstvo se gleda kao na razdoblje životnoga razvoja u kojem su djeca aktivno uključena u svakodnevne aktivnosti, dok se dijete percipira kao subjekt osobnoga rasta i razvoja (Kellett, 2010). Dijete je aktivno, znatiželjno i kompetentno biće koje ima raznovrsne interese, mogućnosti i znanja te, vođeno urođenom znatiželjom, istražuje svijet u sebi 
i oko sebe. Ono je i društveno biće koje od rođenja ulazi u raznovrsne svrhovite interakcije sa svojom okolinom (Muraja, 2012). Sukladno novim pogledima na dijete mijenja se i njegova uloga u obitelji. Ono postaje ravnopravnim članom obitelji koji ima pravo na izražavanje vlastitih ideja i misli te sudjeluje, u skladu sa svojim godinama i psihofizičkim mogućnostima, u donošenju obiteljskih odluka. Jurčević-Lozančić (2005) upozorava da roditelji danas, osim što djetetu moraju osigurati egzistencijalne uvjete, trebaju zadovoljiti i njegove psihološke potrebe za ljubavlju, pažnjom, pripadanjem, zabavom, slobodom te mu pružiti potporu i pomoć u samoostvarivanju. Doeck (2004, prema Pećnik i Starc, 2010) napominje da dijete, osim što ima pravo na brigu, sigurnost i zaštitu, ima pravo i na odgoj koji poštuje njegovu individualnost.

Osim u obitelji, dijete ima novi položaj i u društvu. Tijekom godina doneseni su brojni dokumenti koji štite djecu i njihova prava. Jedan je od njih i Konvencija o pravima djeteta, međunarodni dokument, usvojen na Glavnoj skupštini Ujedinjenih naroda 20. studenog 1989. godine. U Konvenciji se prvenstveno govori o obvezama odraslih spram djeteta. Važno je istaknuti da je Konvencija o pravima djeteta pravni akt koji ima snagu zakona i obvezujući je za sve države koje su ga prihvatile i ratificirale. Republika Hrvatska prihvatila je navedenu konvenciju u listopadu 1991. godine i samim time obvezala se jamčiti svakom djetetu prava u njoj sadržana. Četiri su opća načela na kojima se temelje sva prava u Konvenciji sadržana:

- Djeca ne smiju trpjeti bilo kakav oblik diskriminacije.

- Djeca imaju pravo na život i razvoj u svim aspektima života (tjelesnom, emotivnom, psihosocijalnom, kognitivnom, društvenom i kulturnom).

- Pri donošenju odluka ili izvršavanju postupaka koji se tiču djeteta najvažnija mora biti dječja dobrobit. To se odnosi i na obiteljske kao i na vladine odluke te odluke koje donose zakonodavna tijela.

- Djeca moraju imati mogućnost aktivnoga sudjelovanja u rješavanju svih pitanja koja utječu na njihov život. Ona moraju imati mogućnost iznijeti svoja gledišta koja se moraju ozbiljno uzeti u obzir.

Nadalje, dokumenti koje je također važno spomenuti jer nastoje zaštititi dijete i osigurati mu bolji položaj u društvu jesu Svjetska deklaracija o opstanku, zaštiti i razvoju djece (1990), Svijet dostojan djece (2002), Konvencija Vijeća Europe o zaštiti djece od seksualnog iskorištavanja i seksualnog zlostavljanja (2007), Smjernice Odbora ministara Vijeća Europe o pravosuđu prilagođenom djeci (2010), Preporuke Vijeća Europe o Smjernicama za poštivanje, zaštitu i ostvarivanje prava djece u digitalnom okruženju (2018), Strategija Vijeća Europe za prava djeteta (2016.-2021.) itd.

Nažalost, unatoč postojanju brojnih dokumenata koji štite dijete i njegova prava Fond Ujedinjenih naroda za djecu - UNICEF (engl. United Nations Children's Fund) konstantno upozorava da se ona svakodnevno diljem svijeta učestalo i grubo krše. 


\section{DIJETE U PREDŠKOLSKIM USTANOVAMA}

Rano djetinjstvo razdoblje je intenzivnoga rasta i razvoja djeteta u kojem je ono najranjivije i najosjetljivije na vanjske utjecaje. Garcia i suradnici (2016) ukazuju na važnost ulaganja u razdoblje ranoga djetinjstva jer je to ulaganje koje poslije utječe na kvalitetu života pojedinca (zdravlje, obrazovanje, zapošljavanje, smanjenje kriminala) i napredak društva u cjelini. Hariawan i suradnici (2019) nazivaju ga zlatnim trenutkom koji se nikada više neće ponoviti tijekom dječjega razvoja te ga treba iskoristiti za pružanje najboljega obrazovanja i skrbi u okruženju u kojem se dijete nalazi.

U predškolskim ustanovama većina djece provodi više vremena nego u svojim obiteljima te stoga one moraju pružiti djeci punu podršku u razvoju i ostvarivanju svih njihovih snaga i potencijala. Predškolske ustanove trebaju biti sigurna mjesta prilagođena djeci u kojima će se ona osjećati dobrodošla, slobodno će izražavati svoje misli, ideje i osjećaje, razvijati svoje intelektualne, komunikacijske i socijalne vještine. To su mjesta koja djecu trebaju naučiti toleranciji, međusobnom uvažavanju, pomaganju, suradnji, suosjećanju. Brojni su izazovi pred predškolskim ustanovama, a jedan je od njih i razvoj dječje kreativnosti i stvaralaštva.

Suvremeni pristup razvoju dječje kreativnosti može se razmatrati u okviru koncepcije mentalnoga sklopa, koji može biti razvojni (growth mindset) ili statični mentalni sklop (fixed mindset) (Dweck, 2007). Prema toj koncepciji, ključnu ulogu na motivaciju i postignuća ima percepcija vlastitih sposobnosti. Osobe koje vjeruju da se njihovi talenti mogu razviti (napornim radom, dobrim strategijama i utjecajima drugih osoba) misaono rastu; oni više energije unose u učenje, a manje brinu o tome da izgledaju pametno (Dweck, 2016). Primijenimo li navedenu koncepciju na područje kreativnosti, dijete koje vjeruje da može razviti svoju kreativnost premašit će ono dijete koje vjeruje da je njegova kreativnost unaprijed određena jer je spremno suočiti se s izazovima i nedostatcima koje ispravlja te naporno radi kako bi dosegnulo željeni cilj (Dweck, 2007).

Dijete i predškolska ustanova u međusobnoj su interakciji - predškolska ustanova djeluje na dijete, pomaže mu u rastu i razvoju, obogaćivanju njegovih znanja i sposobnosti, a dijete svojim ponašanjem, djelovanjem i stvaralaštvom djeluje na predškolsku ustanovu; aktivno (s odraslima) sudjeluje u izgradnji njezine kulture. Thacker (2001) kulturu objašnjava kao sklop temeljnih pretpostavki koje stvara određena grupa: razvijajući vanjsko djelovanje organizacije i učeći zajednički rade na postizanju svojih ciljeva. Organizacijsku kulturu čine vrijednosti, uvjerenja, stavovi, norme ponašanja, načini rada, komuniciranja i rješavanja problema (Čulig, 2004, prema Vujičić, 2008). Sudjelovanjem i uključivanjem u raznolike programe, kulturne aktivnosti, u svojem procesu samoostvarenja pojedinac (dijete) postaje sam stvaratelj kulture, odnosno stvaratelj društvenoga i osobnoga identiteta, biva graditeljem kulture (Eagleton, 2002). 
Kvaliteta predškolskih ustanova može se promatrati kroz tri parametra (Arkan i Ozturk, 2019, prema Cobanoglu i Sevim, 2019):

- ljudske resurse;

- kurikulum predškolskih ustanova;

- prostorno-materijalno okruženje.

\section{ULOGA ODGOJITELJA U POTICANJU DJEČJE KREATIVNOSTI I STVARALAŠTVA}

Budući da odgojitelji u predškolskim ustanovama provode dosta vremena s djecom, njihova je uloga ključna u poticanju ili suzbijanju dječje kreativnosti. Kako bi poticali dječju kreativnost, odgojitelji moraju biti svjesni njezine važnosti. Runco (1990) navodi da odgojiteljeve implicitne teorije kreativnosti, koje se temelje na njihovu osobnom sustavu vjerovanja, imaju presudnu ulogu u pristupima poučavanju kao i u očekivanjima koje imaju spram djece. Osim toga, i sami odgojitelji trebaju raditi u okruženju koje potiče njihovu kreativnost. Prema rezultatima provedenih istraživanja kreativan odgojitelj/učitelj opisuje se kao osoba visoko motivirana za rad, otvorena uma, fleksibilna, spremna za cjeloživotno učenje, marljiva, samouvjerena (Bramwell i sur., 2011), ali i brižna, zanimljiva, maštovita, prijateljski raspoložena (Hamza i Griffith, 2006). Odgojitelji koji potiču kreativnost ohrabruju djecu da samostalno tumače znanja, procese i pojave, traže nove informacije i vjeruju u dječje snage i sposobnosti (Alencar, 2002; Runco, 2003). Oni potiču djecu na neobične ideje, dopuštaju njihovoj mašti da dobije kri$l a$, postupno ih vode do originalnih ideja te ih ohrabruju da naprave korak dalje od svakodnevnih i uobičajenih rješenja (Cvetković-Lay i Pečjak, 2004). Uloga odgojitelja i učitelja koji posjeduju razvojni mentalni sklop (growth mindset) ogleda se u činjenici da čine sve kako bi poticali učenje i razvoj djeteta, ali nažalost mnogi deklaratorno izjavljuju da potiču misaoni rast djece, a djeluju suprotno (Dweck, 2015). Osobe koje karakterizira growth mindset usmjerenije su na sam proces, a manje na rezultat toga procesa pa će tako sama kreativna aktivnost biti važnija od uratka koji je iznjedrila ta aktivnost.

Umjetnost i umjetničke aktivnosti utječu na holistički razvoj djeteta i potiču njegovu kreativnost. O odgojiteljima ovisi koliko i na koji će način djeca biti uključena u umjetničke aktivnosti. Odgojitelji koji se osobno zanimaju za likovnu umjetnost vjerojatno će provoditi više likovnih aktivnosti s djecom, dok će odgojitelji koje osobno zanima glazba poticati djecu na sudjelovanje u glazbenim aktivnostima. Kako bi uspješno provodili umjetničke aktivnosti (likovne, glazbene), odgojitelji moraju imati razvijene umjetničke kompetencije i poznavati odgovarajuće nastavne metode kojima mogu potaknuti dječju kreativnost i utjecati na njihov holistički razvoj (Bačlija Sušić i Županić Benić, 2018).

Uvriježeno je kreativnost povezivati s umjetnošću i umjetničkim aktivnostima, no ona se, osobito u ranoj predškolskoj dobi, može poticati kroz sva područja 
dječjega učenja: matematiku, čitanje, usmeno izražavanje, upoznavanje okoliša (prirode). Kreativnost djece predškolske dobi odgojitelj najbolje potiče kroz igru. Igrajući se dijete usvaja osnovne matematičke pojmove (broj, oblik, volumen, prostor), razvija matematičke vještine (zbraja, oduzima, mjeri, dijeli) te traži rješenja matematičkoga problema. Točno rješenje jest važno, no često i ono pogrešno može koristiti i voditi djecu prema boljem razumijevanju, zapažanju, kreativnosti. Čitajući djeci priče, bajke i basne te ih potičući da osmisle njihov nastavak, promijene kraj, uvedu nove likove, odgojitelji kod djece potiču maštu, obogaćuju njihov rječnik. U prirodi mogu upoznati djecu s prirodninama te ih potaknuti na njihovo istraživanje i upoznavanje.

Šagud (2015) ističe kako odgojitelji u dječjim aktivnostima imaju na raspolaganju širok raspon intervencija. Oni mogu direktno ili indirektno podržati igrovno ponašanje, modelirati igru, direktno participirati u njoj, upućivati djecu u nove igrovne situacije, učiniti igru izazovnom i slično.

Povjerenje odgojitelja u dijete ključno je za razvoj kreativnosti. Osim toga, odgojitelji trebaju djeci pružiti mogućnost da bez straha izražavaju svoje zamisli $i$ ideje te ih poticati na sagledavanje situacija i predmeta iz različitih perspektiva. Eckhoff (2011) navodi rezultate istraživanja prema kojima odgojitelji koji smatraju djecu sposobnom razmišljati na originalan i maštovit način te potiču djecu na kreativno izražavanje, kreativnost povezuju s više sadržajnih domena (umjetnost, znanost, čitanje, matematika). To je vrlo važno jer djeluje motivirajuće na djecu i učenje.

Mnogi odgojitelji traže formulu za poticanje dječje kreativnosti. Takva formula im se ne može dati jer ne postoji. Ono što im se može dati neki su načini razmišljanja ili određene strategije. Najvažnije je da odgojitelji shvate i vjeruju da kreativnost nije usko definirana kao dio umjetničkoga obrazovanja već ju je moguće pronaći i njegovati u svakom području učenja. Odgojitelji ne mogu učiniti da djeca budu kreativna. Međutim, odgojitelj može kreirati okruženje koje podržava kreativnost te pripremiti primjerene aktivnosti i materijale za onu djecu koja žele istraživati i kreativno se izražavati. Nedostatak navedenoga može ometati kreativnost (Smith, 1996).

\section{KURIKULUM PREDŠKOLSKIH USTANOVA}

Promjenom percepcije djetinjstva, a time i samoga djeteta, utvrđeni su novi pristupi u istraživanju učenja djece. Dijete ponajprije uči na prirodan način, čineći, ali i igrajući se s drugom djecom (Bašić, 2011). Nove percepcije djeteta $\mathrm{i}$ djetinjstva postale su temelj oblikovanja kurikuluma ranoga i predškolskoga odgoja i obrazovanja. Razvoj kurikuluma predškolskih ustanova kontinuirani je proces. Kurikulum u središte stavlja dijete, njegove potrebe i interese, pri čemu svaki sudionik odgojno-obrazovnoga rada vodi računa o organizaciji, strategiji i metodi ostvarivanja postavljenih zadataka i ciljeva. On omogućuje djetetu da 
kroz konstruktivističko učenje na temelju osobnih aktivnosti i iskustva, uz podršku druge djece i odraslih, samo konstruira svoja znanja. Kurikulum uključuje i visoku razinu fleksibilnosti odgojno-obrazovnoga procesa, što prvenstveno isključuje striktno sadržajno ili vremensko planiranje aktivnosti. To znači da sadržaji nisu polazište odgoja i učenja djeteta, nego su u funkciji njihova ostvarenja. Nacionalni kurikulum za rani i predškolski odgoj $i$ obrazovanje (2014) usmjeren je prema cjelovitu razvoju djeteta te čuvanju i razvijanju nacionalne, duhovne, materijalne i prirodne baštine. Temeljne vrijednosti na kojima počiva su:

- znanje - djetetu pruža mogućnost kritičkoga promišljanja, snalaženja u novim situacijama, kao i uspjeh u svakidašnjem životu i svim kasnijim etapama obrazovanja;

- identitet - priprema dijete da postane građanin svijeta, ali da pritom sačuva svoj nacionalni identitet i svoju kulturu;

- humanizam i tolerancija - odnosi se na prihvaćanje i poštovanje drugih, suosjećanje, pružanje potpore, razumijevanje svojih prava, obveza i odgovornosti te prava, obveza i odgovornosti drugih;

- odgovornost - podrazumijeva promicanje odgovornosti prema općem društvenom dobru, prirodi te prema sebi samima i drugima;

- autonomija - odnosi se na razvoj samostalnoga mišljenja, odlučivanja i djelovanja djeteta;

- $\quad$ kreativnost - podrazumijeva osposobljavanje djeteta za prepoznavanje i iniciranje kreativnih aktivnosti te pronalaženja originalnoga pristupa rješavanju različitih problema.

Dere (2019) smatra da svaki suvremeni kurikulum ranoga i predškolskoga odgoja osobito mora biti usmjeren k poticanju i razvoju dječje mašte i kreativnosti. Djeca moraju imati mogućnost izraziti se na jedinstvene i različite načine u uvjetima koji odgovaraju njihovim potrebama i stilovima učenja. Da bi se to ostvarilo, djeci je potrebno pružiti odgovarajuće mogućnosti. Preduvjet ostvarivanja kreativnih aktivnosti u predškolskim ustanovama s djecom rane i predškolske dobi dostupnost je odgovarajućih tehnika učenja i bogato prostorno-materijalno okruženje (Wyse i Dowson, 2009).

\section{PROSTORNO-MATERIJALNO OKRUŽENJE KAO POTICAJ DJEČJOJ KREATIVNOSTI}

Materijalni uvjeti jedna su od sastavnica konteksta vrtića. Kontekst vrtića čini sigurno, stimulativno prostorno-materijalno i socijalno okruženje u kojem će djeca ostvarivati stalne interakcije, konstruirati individualno i sukonstruirati zajedničko znanje s vršnjacima i odraslima, doživljavati emocije i izražavati ih, isprobavati socijalna umijeća i razvijati tjelesne sposobnosti. Prema Petrović-Sočo (2007) kontekst ustanove za rani odgoj i obrazovanje je ,živi organizam“, složen, dinamičan 
sustav, interaktivna mreža socijalnih, kulturnih i fizičkih odnosa s kojima je dijete u stalnom međudjelovanju jer kontekst djeluje na dijete i obratno.

Važno je naglasiti da prostorno-materijalno okruženje treba biti usmjereno na dijete jer se na taj način uvažava njegova prirodna znatiželja, interes i potreba, omogućuje mu se sloboda izbora te ga se potiče na preuzimanje odgovornosti za svoje izbore i ponašanje (Slunjski, 2011). Prostorno-materijalno okruženje jedan je od najvažnijih čimbenika i o njemu u velikoj mjeri ovisi hoće li se kreativnost djeteta razviti ili će ostati potisnuta (Beghetto i Kaufman, 2014). Okruženje u kojem djeca mogu učiti istraživanjem i rješavanjem problema poticat će i razvijati njihovu kreativnost (Baran, Erdogan i Çakmak, 2011).

Diamond i Hopson (2006) navode nekoliko karakteristika bogaćenja prostorno-materijalnoga okruženja važnoga za razvoj kreativnosti. Takvo okruženje uključuje postojani izvor pozitivne emocionalne potpore, stimulira sva osjetila, u takvom okruženju nema nepotrebna pritiska i napetosti, ali se nudi niz novih izazova koji nisu niti prelagani niti preteški za dijete toga stupnja razvoja. U takvu okruženju potiče se razvoj široka raspona vještina i zanimanja koja su mentalna, fizička, estetska, društvena i emocionalna. Nadalje, daje se djetetu prilika da slobodno bira vlastite aktivnosti, procjenjuje rezultate svojih napora, omogućava ugodnu atmosferu koja potiče istraživanje i zabavu pri učenju te dopušta djetetu da bude aktivan sudionik, a ne pasivni promatrač.

Važnost prostorno-materijalnoga okruženja osobito dolazi do izražaja u Reggio, Montessori i waldorfskom pristupu odgoju i obrazovanju u ranom djetinjstvu. Reggio pristup dijete percipira kao kompetentnoga i sposobnoga pojedinca koji zna izraziti svoje mišljenje, donijeti odluke i surađivati s drugima. Zadatak je odraslih omogućiti djeci da samostalno konstruiraju svoja znanja (Thornton i Brunton, 2014). Djeca uče kroz interakcije s drugom djecom, odgojiteljima i roditeljima. Prostor je organiziran tako da potiče susrete, komunikaciju i uspostavljanje prijateljstva. Ima ulogu trećega odgojitelja jer utječe na to kako se djeca osjećaju, razmišljaju i ponašaju. Prostor treba djeci pružiti osjećaj slobode i ugodna druženja, no isto tako treba ih poticati na istraživanje i rješavanje problema (Gandini, 1998). Malaguzzi (1998) ga opisuje kao svojevrstan akvarij koji je odraz ideja, vrijednosti i kulture onih koji u njemu borave. Prostor svojom organizacijom te bogatstvom materijala i opreme ima važnu ulogu u određivanju načina na koji djeca uče. Rinaldi (2006) ističe da u prostoru mora biti mjesto na kojem djeca mogu: biti kreativna, istraživati, razmišljati, komunicirati, ali i osamiti se.

Prema Montessori pristupu dijete spoznaje vanjski svijet vidom, sluhom, dodirom, okusom i mirisom te je za njegov optimalan razvoj potrebno stimulirati sva navedena osjetila. Prostor u kojem dijete boravi treba biti svijetlih i vedrih boja te poticati pozitivno ponašanje djece. Posebna pozornost pridaje se didaktičkom priboru izrađenom od najboljih prirodnih materijala s pomoću kojega djeca mogu 
samostalno stjecati iskustva. Materijal je na policama dostupan djeci i s pomoću njega ona spoznaju odnose i veze koje vladaju u svijetu (Montessori, 2003).

Waldorfski pristup dijete doživljava prvenstveno kao osjetilno biće i kako bi mu se omogućio optimalan razvoj potrebno mu je osigurati prostorno-materijalno okruženje koje će hraniti sva njegova osjetila. Za pravilnu prehranu osjetila najvažnije je izvorno, prirodno okruženje te se stoga velika pozornost poklanja prirodnim materijalima za igru (drvo, svila), boravku na otvorenom prostoru, radu u vrtu i slično (Steiner, 1995).

Prostor u vrtićima može biti organiziran i u obliku različitih centara aktivnosti, tj. radionica opremljenih različitim materijalima koji su specifični za svaki pojedini centar. Tako se u vrtiću mogu naći brojni centri, kao npr. centar za građenje i konstruiranje, centar za početno čitanje, centar za likovno izražavanje, centar za glazbu, centar za matematiku, tematski centri (liječnik, frizer, pekar...), centar za odmor, centar za osamu. Prostor koji je organiziran na ovaj način omogućuje djetetu odabir aktivnosti prema njegovu osobnom interesu. Centri potiču komunikaciju djece, razmjenu ideja i zajedničko učenje. U njima djeca razvijaju sposobnosti i postaju aktivni sudionici svojega razvoja.

Za razvoj dječje mašte i kreativnosti, uz unutarnje, potrebno je naglasiti važnost i vanjskoga okruženja. Vanjsko okruženje treba pružiti djeci mogućnost igre s nestrukturiranim materijalima koji im omogućuju dodir s prirodom i potiču njihovu maštu jer djeca o sebi i svijetu uče upravo kroz ovu vrstu autentične igre (Wilson, 2012). Okruženje ispunjeno intrigantnim prirodnim materijalima poziva na kreativnu igru nadahnutu dječjom maštom, što je u suprotnosti s gotovim proizvedenim igračkama koje često potiču djecu na djelovanje prema već predviđenim i predvidivim scenarijima. Pogrešno je vjerovanje da je učinkovit način podržavanja dječje kreativnosti igračkama u kojima je izumitelj već sve stvorio. Pripremljeni rekviziti za dramsku igru ne nude izazove i prilike koje nastaju kada djeca moraju pronaći prirodne predmete koje mogu koristiti kako bi predstavili ono što su zamislili. Prirodni predmeti poput štapova, trupaca, lišća, pijeska i snijega mogu biti sve što djeca požele (Kiewra i Veselack, 2016).

\section{DJEČJA KREATIVNOST I STVARALAŠTVO}

Kreativnost je važna vještina koja pomaže djeci bolje funkcionirati i snalaziti se u neizvjesnoj budućnosti koja je pred njima (Craft, 2011). Sastavni je dio svakodnevnoga ljudskog iskustva (Torrance i Gupta, 1964), odnosno način reagiranja na predmete, ideje i situacije (Isenberg i Jalongo, 1997). Za kreativnost se može reći da je unutarnja latentna snaga pojedinca. To je proces koji uključuje određene karakteristike kao što su fleksibilnost, višedimenzionalno razmišljanje, osjetljivost, interes za ljude i okolinu, sposobnost brza razmišljanja i djelovanja, originalnost te mogućnost dolaska do različitih i raznolikih zaključaka (Aral 1990; Tuna 2000; Çakmak i Baran 2005, prema Baran, Erdogan i Çakmak, 2011). Općenito, 
kreativnost se smatra procesom i svi se pojedinci rađaju s različitim osobinama ličnosti (npr. samopouzdanje, znatiželja, tolerancija, motivacija i sl.), sposobnostima (npr. sposobnost divergentnoga mišljenja, osjetljivost na probleme i sl.) i iskustvima što ih čini više ili manje sposobnim izraziti svoj kreativni potencijal (Hamza i Griffith, 2006; Sternberg, Grigorenko i Singer, 2004).

U znanstvenoj i stručnoj literaturi brojne su definicije kreativnosti. Kay (1989, prema Eckhoff, 2011) kreativnost opisuje kao proces u kojem pojedinac pronalazi, definira ili otkriva ideju ili problem koji nije unaprijed određen situacijom ili zadatkom. Robinson (2011) kreativnost vidi kao vrstu maštovita procesa koji rezultira izvornim i vrijednim djelima. Kreativnost se može odrediti i kao stvaranje nečega novog što ranije nije postignuto ili stvoreno (Isbell i Raines, 2007).

Čudina-Obradović (1990) upozorava da je kreativnost pojam koji ima dva značenja. Prvo, kreativnostje stvaralaštvo(stvaranje novihi originalnihumjetničkih, znanstvenih ili tehničkih tvorevina), a drugo, to je osobina ili skup osobina koje omogućuju stvaralaštvo odnosno produktivnost. Vygotsky (2004) stvaralačkim činom smatra svaki ljudski čin koji dovodi do nečega novog bez obzira radi li se o nekom fizičkom objektu, mentalnom ili emocionalnom konstruktu. Navedeni autor ističe da se čovjekovo ponašanje i njegova aktivnost mogu podijeliti na dvije osnovne vrste: reproduktivnu i kreativnu. Reproduktivna aktivnost usko je povezana s pamćenjem i u osnovi se sastoji od toga da osoba reproducira ili ponavlja prethodno razvijene i svladane obrasce ponašanja. Međutim, samo s ovom aktivnošću i ponašanjem čovjek bi se mogao prilagoditi uglavnom poznatim uvjetima okoline, dok sve nove promjene u okolini koje se nisu našle u njegovu prethodnom iskustvu ne bi izazvale odgovarajuće adaptivne reakcije. Stoga, osim reproduktivne, čovjek posjeduje i drugu vrstu aktivnosti u svojem ponašanju koju možemo nazvati kombinatornom ili kreativnom aktivnošću. Sva ljudska aktivnost koja rezultira ne-reprodukcijom prethodno doživljenih dojmova ili radnji, već stvaranjem novih, primjer je kombinatornoga ili kreativnoga ponašanja. Čovjekova kreativnost orijentira ga prema budućnosti, a on ju stvara mijenjajući svoju sadašnjost. Kreativna aktivnost temelji se na sposobnosti našega mozga da kombinira različite elemente, što se u psihologiji naziva maštom ili fantazijom. U svakodnevnom životu mašta ili fantazija upućuju na ono što nije istina i što ne odgovara stvarnosti i što, prema tome, nema ozbiljnijega praktičnog značenja. Međutim, u stvarnosti je mašta kao osnova svih kreativnih aktivnosti važna sastavnica svih aspekata kulturnoga života, omogućujući umjetničko, znanstveno i tehničko stvaranje.

Jedna od prvih izjava o dječjoj kreativnosti bila je ona u Hadowljevu izvještaju 1933. godine (GBBECC, 1933, prema Craft, 2003) u kojoj se nalaze smjernice i preporuke za zaštitu djece rane i predškolske dobi. U izvještaju se naglašava potreba prilagođavanja i usmjeravanja odgoja i obrazovanja malom djetetu kao i važnost pružanja konteksta za dječje samoizražavanje. Ovaj izvještaj bio je važan 
prethodnik Plowdenskom izvještaju (CACE, 1967, prema Craft, 2003), te ih se zajedno može smatrati valom političkih preporuka i aktivnosti u poticanju kreativnosti djece rane i predškolske dobi. Ovaj prvi val povezao je kreativnost s pedagoškim pristupom usmjerenim na dijete. Navedeni izvještaji znatno su utjecali na razvoj liberalnijega razmišljanja o odgoju i obrazovanju djece. Plowdenski izvještaj sugerirao je i na koji način poticati dječju kreativnost. U izvještaju se navodi da je dječja kreativnost:

- benigna;

- u središtu je svih načina učenja i poučavanja;

- prvenstveno je povezana s igrom.

Poslije, krajem 20. i početkom 21. stoljeća, na temelju provedenih istraživanja, nastaju brojni radovi vezani uz poticanje kreativnosti djece rane i predškolske dobi (Craft, 2003; Saracho, 2012; Sternberg i Kaufman, 2018; Vygotsky, 2004).

Kako bi pojam kreativnosti bolje objasnio, Csikszentmihalyi (1996) navodi podjelu kreativnosti na onu s velikim $K$ (engl. Big-C creativity) i onu s malim $k$ (engl. Little-c creativity). Kreativnost s velikim $K$ je rijetka i odnosi se na kreativnost genija (npr. kreativnost Nikole Tesle, Alberta Einsteina, Isaaca Newtona itd.), dok se kreativnost s malim $k$ odnosi na kreativnost u svakodnevnom životu.

Kreativnost s malim $k$ najprikladnija je za istraživanje kreativnosti male djece tijekom njihovih svakodnevnih aktivnosti. Kada se razmatra kreativnost s malim $k$, važno je naglasiti da se pri ocjenjivanju novosti određenoga ishoda ili proizvoda uvijek uzima u obzir znanje i iskustvo pojedinca (Boden, 1992; Ripple, 1989). Craft (2003) navodi kako kreativnost s malim $k$ obuhvaća osobnu djelotvornost, snalažljivost u životu, sposobnost predviđanja i svladavanja prepreka, rješavanja problema. Kod male djece možemo ju razvijati poticanjem njihove snalažljivosti kao i poticanjem na razmatranje i primjenu alternativnih mogućnosti u različitim kontekstima, uključujući igru, međuljudske odnose, zajedničke aktivnosti. Kreativnost s malim $k$ nije nužno vezana za materijalni proizvod budući da ona uključuje vježbanje maštovitosti.

Kreativnost je kod djece potrebno početi razvijati što prije - već od ranoga djetinjstva. Većina teorija o dječjem razvoju djecu vidi kao iznimno kreativnu no isto tako naglašavaju da se taj smisao za kreativnost može izgubiti ako se ne bude razvijala i ako djeca u svojem okruženju ne budu imala dovoljno poticaja za njezin razvoj (Hui i sur., 2015). Kreativni razvoj obuhvaća umjetnost, zanat i dizajn te različite oblike dramske igre i kreativnoga izražavanja, a sve navedeno čini jezgru ranoga djetinjstva. Naglašava se velika uloga mašte te važnost razvoja različitih načina na koje djeca mogu izraziti svoje ideje i prenijeti osjećaje (Craft, 2003).

Kako bi se poticao dječji kreativni potencijal, potrebno je razvijati dječja osjetila. Odrasli trebaju stvoriti uvjete u kojima će djeca moći dodirivati predmete i osjetiti njihovu toplinu, mekoću, hrapavost, mirisati različito cvijeće, slušati različite zvukove u prirodi, doživjeti različite okuse. Dijete se treba poticati da opaža 
i razmišlja, raspravlja s drugima, surađuje. Potrebno ih je poticati na rješavanje problema istraživanjem, eksperimentiranjem, primjenom različitih ideja. Dijete treba ohrabrivati i poticati da pronađe odgovore na pitanja zašto, kako i zbog čega.

Na pitanje zašto su mala djeca kreativnija od odraslih možda najbolje odgovara Gardner (1993), ističući kako djecu ne smetaju nedosljednosti i odstupanje od konvencije, što na kraju rezultira neobičnim kombinacijama. Zapravo, znatan broj stručnjaka vjeruje da su djeca pravo utjelovljenje ljudske kreativnosti (Glaveanu, 2011).

Dječju je kreativnost uglavnom teško procijeniti jer se ona očituje kroz igru i dječje spontano sudjelovanje i izražavanje kroz različite oblike umjetničkih aktivnosti.

\section{IGRA, KREATIVNOST I STVARALAŠTVO}

Igra je sastavni dio dječjih života i u njima zauzima posebno i važno mjesto. Ne postoji jedinstvena definicija igre. Istraživači uglavnom navode njezine karakteristike: dobrovoljno sudjelovanje, zabavna je i pruža osjećaj zadovoljstva, ponašanje u igri gubi svoje uobičajeno značenje, važan je proces, a ne proizvod, odvija se spontano, sama je sebi svrhom i nema nekakav cilj, igra se prema pravilima koja služe organiziranju igre, ali ju čine i zanimljivijom (Eberle, 2014; Lillard i sur., 2013). To je aktivnost u kojoj djeca uživaju i kojoj se uvijek rado vraćaju. Igra je poligon na kojem se usvajaju i usavršavaju brojne životne vještine poput uspostavljanja i održavanja prijateljstva, međusobnoga uvažavanja i podržavanja, dijeljenja, pružanja pomoći, pridržavanja pravila. U igri se mašta, pretvara, eksperimentira. Igra je arena u kojoj djeca mogu iskazati sebe i svoju kreativnost. Duran (2011) ističe igru kao jedinu aktivnost u kojoj se spontano i bez osjećaja neuspjeha isprobavaju razne mogućnosti. Igra je snaga koja dijete vodi u nova otkrića i na viši stupanj razvoja (Rajić i Petrović-Sočo, 2015, str. 605). Ona je prirodna integracija svih ključnih razvojnih segmenata djeteta te najučinkovitiji i iznimno produktivan medij njegova napredovanja (Šagud, 2015, str. 94).

Dječja igra važna je za istraživanje jer uključuje brojne iste kognitivne i emocionalne procese koji se prepoznaju u kreativnosti odraslih. Djecu je važno upoznati s igranjem i kreativnošću u ranoj dobi jer je ključno razumjeti kako igra potiče kreativnost i socio-emocionalni razvoj i obrnuto (Moore i Russ, 2008).

Kreativni procesi kod djece rane i predškolske dobi posebno se zapažaju u igri. Dijete koje sjedi na palici i pretvara se da jaše konja; djevojčica koja se igra lutkom i zamišlja da je ona njezina majka; dječak koji u svojim igrama postane gusar, vojnik ili mornar - sva ta djeca u igri predstavljaju primjere najautentičnijega, istinskog stvaralaštva. Dječja igra vrlo često predstavlja odjek onoga što su vidjeli i čuli da rade odrasli, no ovi elementi njihova prethodnog iskustva nikada se u igri ne reproduciraju onako kako su se dogodili u stvarnosti. Dječja igra nije reprodukcija onoga što su doživjeli, već kreativna preradba i kompilacija dojmova koje su 
stekli. Djeca ih kombiniraju i koriste za konstrukciju nove stvarnosti, one koja je u skladu s njihovim potrebama i željama (Vygotsky, 2004). Igra potiče i oslobađa kreativno mišljenje jer u igri djeca vježbaju različita razmišljanja, koristeći igračke i predmete za predstavljanje različitih stvari i uloga u različitim scenarijima (Singer i Singer, 1990).

Većina autora naglašava važnost dječje simboličke igre za razvoj kreativnosti. U ovoj igri djeca koriste maštu koja dodatno potiče njihov kreativni potencijal (Ivon, 2014; Picciuto i Carruthers, 2014). Kreativno ponašanje definirano je u okviru različitih procesa razmišljanja, što podrazumijeva autentičnost i raznolikost u pronalaženju različitih odgovora na istu situaciju. U simboličkoj igri dijete fleksibilno organizira već poznate dijelove na nov i autentičan način (Ivon, 2014). Pojedinačni objekti u novim situacijama gube svoju uobičajenu funkciju korištenja i dobivaju nov identitet. Predmeti mogu predstavljati sve što dijete zamisli (Rodari, 2001, prema Ivon, 2014). Ova igra omogućava djeci stvaranje uzroka i hipoteza, dopuštajući im da koriste sposobnost razmatranja različitih scenarija. Ona potiče i razvija dječju sposobnost prosuđivanja (Gopnik i Walker, 2013). Simbolička igra pruža djeci mogućnost izražavanja različitih procesa: kognitivnih, afektivnih i međuljudskih, a svi su oni važni za kreativnost. Simboličkom igrom dijete se može koristiti kako bi manipuliralo objektima ili mentalnim slikama, istraživalo zamišljenu špilju, uvježbavalo odlazak u bolnicu, prisjetilo se potisnutih sjećanja, izrazilo pozitivne ili negativne osjećaje (Russ i Wallace, 2013).

I sociodramska igra podupire dječja različita razmišljanja i kognitivnu fleksibilnost što predstavlja osnovne sastavnice kreativnosti (Russ, 2004). Sociodramska igra ili igra pretvaranja je važno obilježje ranoga djetinjstva. Ona uključuje stvaranje alternativnih stvarnosti realnoga svijeta. Djeca mogu kroz igru pretvaranja prikazati različite ljude, mjesta ili vremena, a objekti postaju simboli za ono što se zamišlja (Fein, 1981). Kod sociodramske igre postoji stalna dramska kompozicija i pravila koja određuju redoslijed zamišljenoga događaja u igri, dok kod simboličke navedeno ne postoji (Duran, 2011).

Konstruktivna igra uključuje manipuliranje različitim materijalima za stvaranje/građenje: pijeskom, umjetničkim materijalima (boja, glina, papir), vodom, štapovima, kamenčićima i slično (Wardle, 2000). U konstruktivnoj igri djeca istražuju, rješavaju probleme, surađuju, angažiraju se te veliku pozornost pridaju samom procesu i ishodu svoje igre. Sve navedene aktivnosti djeteta pružaju mu mogućnost razvoja njegova kreativnog potencijala. Ishod dječje konstruktivne igre obično su različite građevine, modeli, planovi i skulpture koje postaju ogledalo dječjega stvaralaštva.

Djelovanje kreativne mašte vrlo je složeno i ovisi o nizu različitih čimbenika. Ova aktivnost ne može biti ista kod djece kao i kod odraslih jer ti čimbenici $\mathrm{u}$ različitim fazama razvoja poprimaju različite oblike. Stoga tijekom svake razvojne faze djetinjstva kreativna mašta djeluje na poseban način karakterističan za 
taj određeni stadij djetetova razvoja. Mašta ovisi i o iskustvu, a poznato je da se djetetovo iskustvo oblikuje i postupno raste. Djetetov odnos prema okolini koji svojom složenošću ili jednostavnošću, tradicijama i utjecajima stimulira i usmjerava njegov proces stvaranja, razlikuje se od odraslih. I interesi djeteta i odraslih se razlikuju te je stoga lako zaključiti da se funkcioniranje dječje mašte razlikuje od mašte odraslih (Vygotsky, 2004).

Istraživanja ukazuju na pad dječje kreativnosti tijekom godina. Analiza rezultata na standardiziranom testu kreativnoga razmišljanja američke djece školske dobi od 1966. do 2008. ukazala je na znatno smanjenje rezultata od 1990. godine. Velik dio pada kreativnosti događa se prije kraja razdoblja ranoga djetinjstva (Kim, 2011). Uzrok pada dječje kreativnosti Howes (2011) vidi u činjenici da se djeca nemaju priliku toliko često igrati koliko su se igrala prije. Ograničavajući i uskraćujući djeci igru ona nemaju mogućnost razvoja kognitivnih, socijalnih i emocionalnih vještina, a samim time ograničen im je i razvoj kreativnosti.

\section{STVARALAŠTVO KROZ UMJETNIČKE AKTIVNOSTI}

Umjetnička područja stvaraju posebno ozračje u predškolskoj ustanovi te predstavljaju moćno sredstvo pri odgoju i obrazovanju djece (Miočić, 2012). Mnoge studije vezane uz kreativnost $u$ ranom djetinjstvu utvrdile su povezanost dječjega kreativnog razvoja i njihova sudjelovanja u nekom obliku umjetničkoga obrazovanja (Bancroft, Fawcett i Hay, 2008).

Svaki oblik kreativne umjetnosti (npr. pokret, ples, umjetnost) ključan je za dječji život. Kada se mala djeca uključe u bilo koju umjetničku aktivnost, ona istražujući uče o svijetu, stvaraju ili se jednostavno samo upoznaju s novim materijalima. Također, ona interpretiraju stvarnost i izražavaju svoje misli i osjećaje. Djeca mogu koristiti umjetnost i kao medij za kreativno izražavanje koji može promovirati njihovu individualnost i kreativnost (Spodek i Saracho, 1994).

Kretanje, jedan od oblika kinestetičke aktivnosti, pomaže djeci razumjeti strukturu pokreta i promiče njihovu tjelesnu vještinu i koordinaciju. Kroz pokrete mala djeca dobiju iskustvo plesa, gimnastike, igre (Spodek i Saracho, 1994). Zachopouloua, Makri i Pollatou (2009) provode istraživanje čiji rezultati ukazuju na povezanost divergentnoga razmišljanja djece predškolske dobi i njihove sposobnosti kretanja. Tjelesno spremnija djeca imaju i bolje jezične vještine u odnosu na svoje vršnjake (Rajović, 2017). Putem kreativnih pokreta mala djeca izražavaju svoje misli, osjećaje i ideje.

Kreativna drama pruža djeci mogućnost spontane i razigrane upotrebe jezika. Za dramu možemo reći i da je strategija koja služi boljem razumijevanju apstraktnih koncepcija i ljudskih iskustava. Različite dramske tehnike omogućuju djeci igru, istraživanje i maštu (Hui i sur., 2015). Istraživanja ukazuju da sudjelovanje djece predškolske dobi u dramskim aktivnostima utječe na razvoj njihove sposobnosti pripovijedanja (Nicolopoulou i Richner, 2007). 
Prema Lugomer (2000/2001), dramski odgoj ne služi samo razvijanju dramske darovitosti i upoznavanju s dramsko-scenskim izrazom. On ima puno šire značenje: pomaže djetetu u razvijanju osjećajnosti, sposobnosti izražavanja, razvoju komunikacijskih vještina, mašte, kreativnosti. Također, s pomoću njega otkrivaju se sklonosti, formiraju stavovi razvija društvena svijest i njezine sastavnice: (samo)kritičnost, odgovornost, snošljivost, razumijevanje međuljudskih odnosa te stjecanje sigurnosti i samopouzdanja. Svrha je dramskoga odgoja odgajanje za život, pripremanje djeteta za susret s realnim svijetom. Važno je razlikovati dramski odgoj od dramske umjetnosti: on nije aktivnost usmjerena na stvaranje kazališne predstave. Osnova drame kao umjetnosti jest dramski izraz temeljen na dramatskom doživljaju svijeta. Dok se u dramskoj umjetnosti dramatski doživljaj svijeta pretvara u umjetnost, u dramskom odgoju (ili dječjoj drami ili kreativnoj dramatici, kako se dramski odgoj još naziva) on se pretvara u organiziranu igru.

Glazba je prisutna na razne načine u dječjim životima još od njihove rane dobi. Ona predstavlja važnu sastavnicu cjelovita dječjeg razvoja. Glazbene aktivnosti trebale bi biti utkane u svakodnevne dječje aktivnosti i igru. Aktivni doživljaj glazbe koji se javlja sudjelovanjem u različitim oblicima glazbenih aktivnosti temelj je dječjega spontanoga glazbenog stvaralačkog izraza. U predškolskim ustanovama važno je posvetiti pozornost onim glazbenim aktivnostima koje pridonose razvoju dječjega inherentnoga kreativnog potencijala (Bačlija Sušić, 2018). Osim razvoja dječje kreativnosti i stvaralaštva, glazbenom umjetnošću afirmira se kritičko i estetsko promišljanje te se stvara mogućnost osobne nadogradnje pojedinca kao i kulturnoga prosperiteta. U predškolskim ustanovama kroz raznolika glazbena iskustva razvija se estetski potencijal djeteta (Pesec, 1997, prema Miočić, 2012). Glazbene aktivnosti jednostavno trebaju djeci omogućiti uživanje u glazbi (Slunjski, 2013). Glazba u vrtiću omogućava da se doživljava i živi kultura (Petrović-Sočo, 2007).

Dječja želja za crtanjem i izmišljanjem priča potiče maštu i kreativnost. Npr. dječak koji vidi hroma čovjeka na ulici sam smišlja priču - muškarac je jahao konja i na velikoj, oštroj stijeni ozlijedio nogu. Sada je u potrazi za lijekom od kojega će mu biti bolje. U ovom je primjeru evidentno djelovanje mašte. Svi elementi ove situacije djetetu su poznati iz njegova prethodnog iskustva, međutim kombinacija ovih elemenata je nešto novo, kreativno, nešto što pripada samom djetetu i ne reproducira jednostavno samo ono što je dijete slučajno vidjelo ili zapazilo. Upravo ta sposobnost kombiniranja elemenata za proizvodnju nove strukture, odnosno kombiniranje staroga na nove načine osnova je kreativnosti (Vygotsky, 2004).

I vizualne umjetnosti zauzimaju važno mjesto u odgoju i obrazovanju djece rane i predškolske dobi. Međutim, one kod djece potiču kreativnost samo kada im odgojitelji daju slobodu samostalnoga eksperimentiranja s likovnim izražavanjem i stvaranjem. Vizualno-kreativne aktivnosti omogućuju djeci da istraže na koji način mogu izraziti svoje misli, ideje i iskustva iz vanjskoga svijeta, koristeći različite 
likovne materijale i tehnike. Uloga odgojitelja u predškolskim ustanovama jest pripremiti, ohrabriti i motivirati djecu da se izraze koristeći likovnu umjetnost $\mathrm{u}$ okruženju koje je osmišljeno i organizirano tako da olakšava kreativne procese i potiče kreativne aktivnosti (Balić Šimrak, Šverko i Županić Benić, 2010, prema Bačlija Sušić i Županić Benić, 2018).

Kreativnost zauzima središnje mjesto u svim granama umjetnosti i zahvaljujući njihovoj bogatoj raznolikosti pružaju se neograničene i jedinstvene mogućnosti za njezin razvoj (Prentice, 2000).

Dječji razvoj može ići u dva smjera: prema dosezanju postojećih oblika kulture ili stvaranju novih oblika kulture koji još ne postoje, a to je onda prostor aktualizacije djeteta (Veraksa, 2018). Tendencija suvremenoga otvorenoga kurikuluma, usmjerenoga djetetovu holističkom razvoju trebala bi težiti njegovoj samoaktualizaciji. Poticajno materijalno okruženje i odgojitelji koji usmjeravaju dječju aktivnost kreativnom načinu mišljenja i djelovanja stvaraju pogodne uvjete da dijete postane suvremeni stvaratelj kulture.

\section{ZAKLJUČAK}

Poticanje dječje kreativnosti danas se smatra ključnim obrazovnim ciljem u mnogim obrazovnim sustavima širom svijeta (Kampylis, 2010).

Kreativni pojedinci danas predstavljaju najveće bogatstvo društva. Oni su pokretači promjena, aktivni sudionici društvenoga rasta i razvoja. Za tu važnu ulogu treba ih pripremati od najranije dobi. Rano djetinjstvo razdoblje je u kojem je dijete najosjetljivije na vanjske utjecaje te ga treba iskoristiti i pružiti mu najbolju skrb i obrazovanje. U tom razdoblju iznimno je važno poticati dječju kreativnost. To se u predškolskim ustanovama postiže omogućavajući djetetu boravak u poticajnom prostorno-materijalnom okruženju te kreiranjem fleksibilnoga kurikuluma orijentiranoga na dijete i na poticanje njegove mašte i kreativnosti. U razvoju dječje kreativnosti važnu ulogu imaju i odgojitelji. Kako bi ju uspješno razvijali kod djece, oni moraju biti svjesni njezine važnosti, vjerovati u dijete i njegove sposobnosti, kontinuirano se stručno usavršavati te i sami raditi u okruženju koje potiče njihovu kreativnost. Sudjelujući u kreativnim aktivnostima, kreativno se izražavajući i stvarajući, djeca zajedno s odgojiteljima postaju graditelji kulture svoje ustanove, a kultura, prema navodima autorica Ljubetić i Slunjski (2012), čini bit svake zajednice i daje joj $d u \check{s} u$, te ju čini jedinstvenom, prepoznatljivom i neponovljivom; čini ju ugodnom ili neugodnom, zdravom ili nezdravom, poželjnom ili nepoželjnom. Kultura znatno određuje kvalitetu života i učenja svih članova te zajednice - i djece i odraslih. 


\section{LITERATURA}

1. Alencar, E. (2002). Mastering creativity for education in the 21st century. U B. Clark (ur.), Proceedings of the 13th Biennial World Conference of the World Council for Gifted and Talented Children (str. 13-21). World Council for Gifted and Talented Children.

2. Bačlija Sušić, B. (2018). Dječje glazbeno stvaralaštvo: stvaralački i autotelični aspekt. Metodički ogledi, 25(1), 63-83.

3. Bačlija Sušić, B. i Županić Benić, M. (2018). Preschool Teachers' Sensibility in Music and Visual Arts as a Foundation for Encouraging Creative Expression in Children. Croatian Journal of Education, 20(3), 93-105.

4. Bancroft, S., Fawcett, M. i Hay, P. (2008). Researching Children Researching the World: $5 X 5 X 5=$ creativity. Trentham Books.

5. Baran, G., Erdogan, S. i Çakmak, A. (2011). A Study on the Relationship between SixYear-Old Children's Creativity and Mathematical Ability. International Education Studies, 4(1), 105-111.

6. Bašić, S. (2011). (Nova) slika djeteta u pedagogiji djetinjstva. U D. Maleš (ur.), Nove paradigme ranog odgoja (str. 19-37). Filozofski fakultet Sveučilišta u Zagrebu, Zavod za pedagogiju.

7. Beghetto, R. A. i Kaufman, J. C. (2014). Classroom context for creativity. High Ability Studies, 25(1), 53-69.

8. Bramwell, G., Reilly, R., Lilly, F., Kronish, N. i Chennabathni, R. (2011). Creative teachers. Roeper Review, 33(4), 228-238.

9. Boden, M. A. (1992). The creative mind: Myths and mechanisms. Basic Books.

10. Cobanoglu, F. i Sevim, S. (2019). Child-Friendly Schools: An Assessment of Kindergartens. International Journal of Educational Methodology, 5(4), 637-650.

11. Craft, A. (2003). Creative thinking in the early years of education. Early Years, 23(2), $143-154$.

12. Craft, A. (2011). Creativity and education futures: Learning in a digital age. Trentham Books.

13. Csikszentmihalyi, M. (1996). Creativity: Flow and the psychology of discovery and invention. Harper Collins Publishers.

14. Cvetković-Lay, J. i Pečjak, V. (2004). Možeš i drugačije: priručnik s vježbama za poticanje kreativnog mišljenja. Alinea.

15. Čudina-Obradović, M. (1990). Nadarenost: razumijevanje, prepoznavanje, razvijanje. Školska knjiga.

16. Dere, Z. (2019). Investigating the Creativity of Children in Early Childhood Education Institutions. Universal Journal of Educational Research, 7(3), 652-658.

17. Diamond, M. i Hopson, J. (2006). Čarobno drveće uma: kako razvijati inteligenciju, kreativnost i zdrave emocije vašeg djeteta od rođenja do adolescencije. Ostvarenje.

18. Duran, M. (2011). Dijete i igra (4. izd.). Naklada Slap.

19. Dweck, C. (2007). Boosting achievement with messages that motivate. Education Canada, 47(2), 6-10. 
M. Đuranović, I. Klasnić, I. Matešić: Poticanje dječje kreativnosti...

20. Dweck, C. (2015). Carol Dweck Revisits the 'Growth Mindset. Education Week, 35(5). https://www.edweek.org/ew/articles/2015/09/23/carol-dweck-revisits-the-growth-mindset.html?qs=carol+dweck (15. 7. 2020.)

21. Dweck, C. (2016). What Having a "Growth Mindset" Actually Means. Harvard Business Review, 13, 213-226.

22. Eagleton, T. (2002). Ideja kulture. Naklada Jesenski i Turk.

23. Eberle, S. G. (2014). The Elements of Play: Toward a Philosophy and a Definition of Play. American Journal of Play, 6(2), 214-233.

24. Eckhoff, A. (2011). Creativity in the Early Childhood Classroom: Perspectives of Preservice Teachers. Journal of Early Childhood Teacher Education, 32(3), 240-255.

25. Fass, P. S. (2004). Encyclopedia of Children and Childhood: In History and Society. Macmillan Reference.

26. Fein, G. G. (1981). Pretend play in childhood: An integrative review. Child Development, 52(4), 1095-1118.

27. Gandini, L. (1998). Educational and caring spaces. U C. Edwards, L. Gandini i G. Forman (ur.), The hundred languages of children: The Reggio Emilia approachAdvanced reflections (2nd ed., str. 161-178). Ablex Publishing.

28. Garcia, J. L., Heckman, J. J., Leaf, D. E. i Prados, M. J. (2016). The Life-cycle Benefits of an Influential Early Childhood Program (NBER Working Paper No. 22993). https://www.nber.org/papers/w22993.pdf (20. 3. 2020.)

29. Gardner, H. (1993). Frames of mind: The theory of multiple intelligences (10th anniversary ed.). Basic Books.

30. Glaveanu, V. P. (2011). Children and creativity: a most (un)likely pair? Thinking skills and creativity, 6(2), 122-131.

31. Gopnik, A. i Walker, C. M. (2013). Considering Counterfactuals: The Relationship between Causal Learning and Pretend Play. American Journal of Play, 6(1), 15-28.

32. Hamza, M. i Griffith, K. (2006). Foster problem solving \& creative thinking in the classroom: cultivating a creative mind. National Forum of Applied Educational Research Journal-Electronic, 19(3), 1-30.

33. Hariawan, R., Ulfatin, N., Huda, A. Y. M. i Arifin, I. (2019). Contributions Management of Parenting and Education Program to Strengthen the Service Three Early Childhood Education Center. International Education Studies, 12(2), 100-108.

34. Howes, C. (2011). Social Play of Children with Adults and Peers. U A. D. Pellegrini (ur.), The Oxford Handbook of the Development of Play (str. 231-244). Oxford University Press.

35. Hui, A., Chow, B., Chan, A., Chui, B. i Sam, C. (2015). Creativity in Hong Kong classrooms: transition from a seriously formal pedagogy to informally playful learning. Education, 43(4), 393-403.

36. Isbell, R. T. i Raines, S. C. (2007). Creativity and the arts with young children. Thomson Delmar Learning.

37. Isenberg, J. P. i Jalongo, M. R. (1997). Creative expression and play in early childhood. Prentice-Hall, Inc.

38. Ivon, H. (2014). Features of Children's Play and Developmental Possibilities of Symbolic Puppet Play. Croatian Journal of Education, 16(1), 161-180.

39. Jurčević-Lozančić, A. (2005). Izazovi odrastanja. Visoka učiteljska škola u Petrinji. 
40. Kampylis, P. (2010). Fostering creative thinking: The role of primary teachers. University of Jyväskylä.

41. Kellett, M. (2010). Rethinking Children and Research, Attitudes in Contemporary Society. Continuum International Publishing Group.

42. Kiewra, C. i Veselack, E. (2016). Playing with Nature: Supporting Preschoolers' Creativity in Natural Outdoor Classrooms. International Journal of Early Childhood Environmental Education, 4(1), 70-95.

43. Kim, K. H. (2011). The Creativity Crisis: The Decrease in Creative Thinking Scores on the Torrance Tests of Creative Thinking. Creativity Research Journal, 23(4), 285-295.

44. Konvencija o pravima djeteta (1989). https:/www.unicef.hr/wp-content/uploads/2017/05/Konvencija_20o_20pravima_20djeteta_full.pdf (20. 3. 2020.)

45. Konvencija Vijeća Europe o zaštiti djece od seksualnog iskorištavanja i seksualnog zlostavljanja (2007). https://dijete.hr/dokumenti/medunarodni-dokumenti/ (21. 3. 2020.)

46. Lillard, A. S., Lerner, M. D., Hopkins, E. J., Dore, R. A., Smith, E. D. i Palmquist, C. M. (2013). The Impact of Pretend Play on Children's Development: A Review of the Evidence. Psychological Bulletin, 139(1), 1-34.

47. Lugomer, V. (2000/2001). Dramski odgoj u nastavi. Školske novine. http://www. hcdo.hr/knjiznica/strucni-clanci/valentina-kamber-dramski-odgoj-u-nastavi/ (23. 5. 2020.)

48. Ljubetić, M. i Slunjski, E. (2012). From the Traditional to the Modern: The Culture of Kindergartens Communities That Learn (The Croatian Experience). World Journal of Education, 2(3), 49-56.

49. Malaguzzi, L. (1998). History, ideas, and basic philosophy: An interview with Lella Gandini. U C. Edwards, L. Gandini i G. Forman (ur.), The hundred languages of children: The Reggio Emilia approach-Advanced reflections (2nd ed., str. 49-98). Ablex Publishing.

50. Miljković, D. (2009). Pedagogija za sportske trenere. Odjel za izobrazbu trenera Društvenog Veleučilišta u Zagrebu; Kineziološki fakultet Sveučilišta u Zagrebu.

51. Miočić, M. (2012). Kultura predškolske ustanove u svjetlu glazbenih kompetencija odgojitelja. Magistra Iadertina, 7(7), 73-87.

52. Montessori, M. (2003). Dijete - tajna djetinjstva. Naklada Slap.

53. Moore, M. i Russ, S. W. (2008). Follow-up of a pretend play intervention: Effects on play, creativity, and emotional processes in children. Creativity Research Journal, 20(4), 427-436.

54. Muraja, J. (2012). Priručnik za samovrednovanje ustanova ranoga i predškolskog odgoja i obrazovanja. Nacionalni centar za vanjsko vrednovanje obrazovanja.

55. Nacionalni kurikulum za rani i predškolski odgoj i obrazovanje (2014). Ministarstvo znanosti, obrazovanja i športa.

56. Nicolopoulou, A. i Richner, E. S. (2007). From Actors to Agents to Persons: The Development of Character Representation in Young Children's Narratives. Child Development, 78(2), 412-429.

57. Pećnik, N. i Starc, B. (2010). Roditeljstvo u najboljem interesu djeteta i podrška roditeljima najmlađe djece. Ured UNICEF-a za Hrvatsku. 
M. Đuranović, I. Klasnić, I. Matešić: Poticanje dječje kreativnosti...

58. Petrović-Sočo, B. (2007). Kontekst ustanove za rani odgoj i obrazovanje - holistički pristup. Mali profesor.

59. Picciuto, E. i Carruthers, P. (2014). The Origins of Creativity. U E. S. Paul i S. B. Kaufman (ur.), The Philosophy of Creativity (str. 199-223). Oxford University Press.

60. Prentice, R. (2000). Creativity: a reaffirmation of its place in early childhood education. The Curriculum Journal, 11(2), 145-158.

61. Preporuke Vijeća Europe o Smjernicama za poštivanje, zaštitu i ostvarivanje prava djece u digitalnom okruženju (2018). http://www.djecjidompula.hr/wp-content/ uploads/2017/03/Smjernice-za-po $\%$ C5\%A1tivanje-za $\%$ C5\%A1 titu-i-ostvarivanjeprava-djeteta-u-digitalnom-okru\%C5\%BEenju-22.10.2018.-1.pdf (15. 4. 2020.)

62. Rajić, V. i Petrović-Sočo, B. (2015). Dječji doživljaj igre u predškolskoj i ranoj školskoj dobi. Školski vjesnik, 64(4), 603-620.

63. Rajović, R. (2017). Kako igrom uspješno razvijati djetetov IQ? Harfa.

64. Rinaldi, C. (2006). In Dialogue with Reggio Emilia: Listening, Researching and Learning. Routledge.

65. Ripple, R. E. (1989). Ordinary creativity. Contemporary Educational Psychology, 14(3), 189-202.

66. Robinson, K. (2011). Out of our minds: Learning to be creative. Capstone Publishing.

67. Runco, M. A. (1990). Implicit theories and ideational creativity. U M. A. Runco i R. S. Albert (ur.), Theories of creativity (str. 234-252). Sage Publications, Inc.

68. Runco, M. A. (2003). Education for creative potential. Scandinavian Journal of Educational Research, 47(3), 317-324.

69. Russ, S. W. (2004). Play in child development and psychotherapy: Toward empirically supported practice. Lawrence Erlbaum Associates, Inc., Publishers.

70. Russ, S. W. i Wallace, C. E. (2013). Pretend Play and Creative Processes. American Journal of Play, 6(1), 136-148.

71. Saracho, O. N. (ur.) (2012). Contemporary Perspectives on Research in Creativity in Early Childhood Education. Information Age Publishing.

72. Singer, D. i Singer, J. L. (1990). The House of Make-believe. Harvard University Press.

73. Slunjski, E. (2011). Kurikulum ranog odgoja. Školska knjiga.

74. Slunjski, E. (2013). Kako djetetu pomoći da ... bude pametno na različite načine: priručnik za roditelje, odgajatelje i učitelje. Element.

75. Smith, M. K. (1996). Fostering Creativity in the Early Childhood Classroom. Early Childhood Education Journal, 24(2), 77-82.

76. Smjernice Odbora ministara Vijeća Europe o pravosuđu prilagođenom djeci (2010). https://dijete.hr/dokumenti/medunarodni-dokumenti/ (10. 4. 2020.)

77. Spodek, B. i Saracho, O. N. (1994). Right from the start: Teaching children ages three to eight. Allyn \& Bacon.

78. Steiner, R. (1995). Pedagoška osnova i ciljevi waldorfske škole. Društvo za waldorfsku pedagogiju Hrvatske.

79. Sternberg, R. J., Grigorenko, E. L. i Singer, J. L. (Ed.). (2004). Creativity: From potential to realization. American Psychological Association. 
80. Sternberg, R. J. i Kaufman, J. C. (2018). The Big Questions in the Field of Creativity Now and Tomorrow. U R. J. Sternberg i J. C. Kaufman (ur.), The nature of human creativity (str. 374-380). Cambridge University Press.

81. Strategija Vijeća Europe za prava djeteta (2016.-2021.). https://dijete.hr/dokumenti/ medunarodni-dokumenti/ (17. 4. 2020.)

82. Svijet dostojan djece (2002). Državni zavod za zaštitu obitelji, materinstva i mladeži.

83. Svjetska deklaracija o opstanku, zaštiti i razvoju djece (1990). http://www.un-documents.net/wsc-dec.htm (17. 4. 2020.)

84. Šagud, M. (2015). Komunikacija odgajatelja i djece u igri i strukturiranim aktivnostima. Školski vjesnik, 64(1), 91-111.

85. Šagud, M. (2015a). Contemporary Childhood and the Institutional Context. Croatian Journal of Education, 17(1), 265-274.

86. Thacker, J. (2001). Osobno, društveno i moralno obrazovanje. U Ch. Desforges (ur.), Uspješno poučavanje i učenje (str. 249 - 267). Educa.

87. Thornton, L. i Brunton, P. (2014). Bringing the Reggio Approach to your Early Years Practice (3rd ed.). Routledge.

88. Torrance, E. P. i Gupta, R. K. (1964). Programmed experiences in creative thinking: Final report on Title VII Project to the US office of education. University of Minnesota.

89. Veraksa, N. E. (2018). Child Development: Two Paradigms. Cultural-Historical Psychology, 14(2), 102-108.

90. Vujičić, L. (2008). Kultura odgojno-obrazovne ustanove i kvaliteta promjena odgojno-obrazovne prakse. Pedagogijska istraživanja, 5(1), 7-21.

91. Vygotsky, L. S. (2004). Imagination and Creativity in Childhood. Journal of Russian and East European Psychology, 42(1), 7-97.

92. Wardle, F. (2000). Supporting Constructive Play in the Wild. Child Care Information Exchange, 5, 26-29.

93. Wilson, R. (2012). Nature and young children: Encouraging creative play and learning natural environments ( 2 nd ed.). Routledge.

94. Wyse, D. i Dowson, P. (2009). The Really Useful Creativity Book. Routledge.

95. Zachopouloua, E., Makri, A. i Pollatou, E. (2009). Evaluation of children's creativity: psychometric properties of Torrance's 'Thinking Creatively in Action and Movement' test. Early Child Development and Care, 179(3), 317-328.

96. Zaninović, M. (1988). Opća povijest pedagogije. Školska knjiga.

97. Žlebnik, L. (1955). Opća povijest pedagogije. Pedagoško-književni zbor. 